\title{
EFFECT OF IN OVO NANO-SELENIUM AND GLUTAMINE ON HATCHABILITY, POST-HATCH PERFORMANCE AND SOME BLOOD BIOCHEMICAL INDICES IN JAPANESE QUAIL
}

\author{
Sallam $^{1^{*}}$ M.G., El-Wardany ${ }^{2}$ I., Abdel-Fattah ${ }^{2}$ S.A., El-Mallah' G.M. \\ and Yassein ${ }^{1}$ S.A.
}

1- Animal Production Dept., Agric. and Biological Research Division, National Research Centre, Giza, Egypt

2- Poultry Production Dept., Fac. of Agric., Ain Shams Univ., P.O. Box 68, Hadayek Shubra 11241, Cairo, Egypt

*Corresponding author: mohamed sallam@agr.asu.edu.eg

\section{ABSTRACT}

A total number of 500 Japanese quail fertile eggs were used to study the effect of in ovo (IO) administration of Nano-Selenium (Nano-Se) and Glutamine (GIn) on hatchability, post hatch performance carcass and some blood biochemical traits. Eggs were divided into five treatments groups and injected just before incubation. The $1^{\text {st }}$ group was not injected (Negative Control;T1), the $2^{\text {nd }}$ one was injected with Bovine Serum Albumin (BSA) (Positive control; T2), the $3^{\text {rd }}$ group was injected with Nano-Se at $2.5 \mathrm{ppb} / \mathrm{egg}$ (T3), while, the $4^{\text {th }}$ (T4) and $5^{\text {th }}$ (T5) groups were injected with glutamine at 20 and $10 \mathrm{ppm} / \mathrm{egg}$, respectively. The hatched chicks were distributed according to their treatments and reared up to the $6^{\text {th }}$ week of age. Parameters such as the hatchability, hatchlings weight, productive performance, carcass traits and some blood biochemical indices were estimated. The IO-GIn at $20 \mathrm{ppm}$ (T4) significantly improved hatchability, increased the productive performance of post-hatch quails (carcass weight, gizzard and breast muscles percentages) and enhanced the feed conversion ratio (FCR) compared to other groups. Furthermore, IO with Nano-Se (T3) significantly increased plasma albumin and albumin / globulin $(A / G)$ ratio, and decreased cholesterol and triglycerides levels, while high density lipoprotein (HDL) were significantly increased and low density lipoprotein (LDL) were significantly decreased by IO-GIn (T4 and T5). It could be concluded that using the in ovo administration of Nano-Se and GIn concentration for Japanese quail breeder eggs, had no negative effect on hatchability and could improve post-hatched performance carcass traits, particularly using Gln at a dosage of 20 ppm / egg.

Keywords: In Ovo, Nano-Selenium, Glutamine, Hatchability, Performance, Quail

\section{INTRODUCTION}

In ovo (IO) considers the method of providing exogenous substances for the avian embryos (Uni and Ferket, 2003), that improve the chicks performance from injected eggs (Salmanzadeh, 2011; Salmanzadeh et al 2012 and Dong et al 2013). The methods of in ovo materials ensure an acceptable nutrient content in egg with injected nutrients that increase hatching weight and supply embryos with extra nutrients and energy (Uni et al 2005 and Foye et al 2006a). Uni and Ferket (2003) considers the in ovo injection technology is a safety method to conduct the external materials to embryonic development. Also, during the incubation, the injected materials are swallowed, digested and absorbed by the embryo, respectively before piping (Uni et al 2005).

Selenium (Se) is the essential micro-nutrient plays an important role in a number of biological processes, activates glutathione peroxidise and seleno-enzymes which can help in protecting from the free radicals, which destroy body cells and reducing the immunity. The introduction of IO-Se to the incubating embryo was found to be a suitable alternative. Since, Se deficiency in poultry diets caused several pathological conditions that can 
harm growth and development. In ovo nanoparticles acting as active agents and carriers of nutrient that helps of nano-nutrition to support embryos with bioactive substances (Sawosz et al 2012).

Glutamine (GIn), one of the amino acids that involved in the protein and carbohydrate metabolism and are a distinct supplier of the amino group for endogenous amino acids synthesis. Furthermore, Gln is the major motive power for gastrointestinal tract development (Andrew and Griffiths, 2002), It is also reduce high ammonia levels from protein catabolism, necessary for uric acid synthesis and a source of arginine (Bertolo and Burrin, 2008). Gln is the main source for rapidly proliferating cells specially activated lymphocytes and intestinal enterocytes (Calder and Yaqoob, 1999) besides a small intestine barrier of the mucus (Le Bacquer et al 2003). Also, amino acids are essential for glycogen synthesis that limits for protein synthesis owing to limited carbohydrate storage in the eggs (Sunny et al 2007).

Thus, the present study illustrates the response of Japanese quail breeder eggs subjected to in ovo administration with nano-selenium or glutamine on hatchability, post-hatch performance, carcass yield, digestive organs (including: small intestine, liver, gizzard), breast muscles and some blood plasma constituents.

\section{MATERIALS AND METHODS}

The present study was performed at the Quail Production Unit, Agricultural Experiments and Research Station, Fac. of Agric., Ain Shams Univ. Farm at Shalaqan, Qalyubia, Egypt, during the period from May to July 2017.

\section{Experimental Design}

A total number of 500 fertilized fresh eggs of 12 weeks old Japanese quail breeders flock were used in this study. A day before setting in the incubator, eggs were numbered, weighed individually and randomly divided into five experimental groups (100 eggs / group) and subjected to injection in air cell just before incubation as follows: The $1^{\text {st }}$ group (T1) was used negative control and not injected; the $2^{\text {nd }}$ was considered as (T2) positive control injected with bovine serum albumin (BSA) that was used to dissolve Nano-Se. The $3^{\text {rd }}(\mathrm{T} 3), 4^{\text {th }}$ (T4) and $5^{\text {th }}$ (T5) groups were received Nano-Selenium (2.5 ppb / egg), Glutamine (20 ppm/egg), Glutamine (10 ppm / egg), respectively.

\section{Experimental procedures}

Nano form of selenium was prepared by adopting the procedure of Razi et al (2011), while the concentration of glutamine in the in ovo injection solution was formulated to the amino acid composition of albumin by Belitz et al (2009). The open holes of injected eggs were covered by non-toxic glue according to Bhanja (2004).

\section{Measurements and observations}

\section{Hatchability percentage}

Hatchability percentage was calculated based on the number of hatched chicks as a percentage of the in ovo treated eggs at hatch. Also, chicks weight were recorded.

\section{Birds and Data collection}

The hatched chicks of all treatments were individually weighed, a total number of 45 birds for each treatment were randomly taken and assigned to three replicates (15/ replicate). Chicks of all treatment groups were housed in galvanized cages up to the age of six weeks. Water and feed were let for ad libitum consumption. Feed was formulated to meet the recommendations of NRC (1994). Generally, all chicks were kept under similar managerial and hygienic conditions.

Measurements: hatchability percentage was calculated at the end of incubation period based on the number of fertile eggs. Live body weight (LBW) and feed intake (FI) were recorded for bi-weekly interval throughout the growth period, however the average final body weights were presented weight gains (WG) were calculated. At the end of the experiment period (6 weeks), 35 quails ( 7 quails / treatment) were randomly taken, slaughtered, defeathered, opened and the weights of eviscerated carcases were recorded. Breast muscles and the internal organs (liver, gizzard and small intestine) were removed and separately weighed and proportionated to pre-slaughtering body weight. Blood samples were collected at slaughtering time in heparinized tubes. Plasma were harvested after centrifugation (4000 rpm for $15 \mathrm{~min}$.), then stored at $-20^{\circ} \mathrm{C}$ until the analyses of some blood constituents were done.

Plasma Total Protein was determined according to Tietz (1994). Albumin was determined according to Tietz (1990). Globulin values were calculated by subtracting albumin values from total 
protein values for each replicate within each treatment. Albumin / Globulin ratio (A / G ratio) values were calculated by dividing albumin values on globulin values for each replicate within each treatment.

Cholesterol concentration was determined according to NCEP (1988). Triglycerides were determined according to Young (1975). HDL Cholesterol was determined according to Lopes-Virella (1977). LDL Cholesterol values were estimated by the following formula according to Friedewald (1972):

$\underset{\text { Cholesterol }}{L D L}=\begin{gathered}\text { Total } \\ \text { Cholesterol }\end{gathered}-\frac{\text { Triglycerides }}{5}-\begin{gathered}H D L \\ \text { Cholesterol }\end{gathered}$

\section{Statistical analysis}

Data were statistically analyzed using Analysis of Variance procedure using the General Linear Model (GLM) of SAS (2002) using the following model:

$$
Y_{i j}=\mu+T_{i}+e_{i j}
$$

Where:

$Y_{i j}=$ The observed value of a given dependent variable.

$\mu=$ Overall mean.

$T_{i}=$ The effect of treatment

$e_{i j}=$ The experimental error

The differences among means were tested using Duncan's multiple range test (Duncan, 1955).

\section{RESULTS AND DISCUSSION}

The results obtained from 10 (Nano-Se and GIn) are shown in Fig. (1). It is observed that the IO-GIn at 20ppm/egg (T4) had the highest hatchability percentage while, the lowest percentage was recorded by Nano-Se treatment (T3) compared with the other experimental groups. The results of this study confirm the results of Uni et al. (2005) who proved that IO-GIn indicates a positive effect during the late period of embryogenesis on increasing the hatchability percentage. Whereas, no effect was noted on hatchability when used IO- GIn at the $18^{\text {th }}$ day of incubation as reported by Pedroso et al (2006b). In this connection, the newly hatched chicks were not affected by using $0.5 \mathrm{ml}$ of $10 \%$ IO-GIn solution (Dos Santos et al 2010). However, improving energy status of embryos and muscles protein from mobilization as a result for IO-GIn helps to improve hatchability and growth as cleared by Tako et al (2004a); Tong and Barbut (2004); Uni et al (2005); Foye et al (2006b) and Shafey et al (2010). The hatchability results of injecting Nano-Se in our study was nearly coincided with those of Patric et al (2016) who proved that IO-Nano-Se at 5 ppm level did not significantly influence the hatchability \%. In general, as reported by Uni and Ferket (2004) showed that the reaction of 10 rely on heredity, hatching eggs, conditions of incubation and the eggs size.

Results presented in Table (1) shows the response of IO Nano-Se and Gln on performance of Japanese quail chicks. A significant increase existed in final body weight (BW) and body weight gain (BWG) in the treatments of positive control (T2) and Gln (T4 and T5) than the negative control (T1) and Nano-Se (T3).

In this respect, several previous studies showed that, to increase the growth performance of newly hatched-chicks, it is important to stimulate the development of chick embryo (Tako et al 2004b; Uni et al 2005 and Smirnov et al 2006). The feed intake (FI) of IO-GIn (T4) was significantly decreased compared to the other treatments. Results of FCR showed that, it was improved $(p<0.0001)$ by IO of Gln at 20 ppm, followed by Gln at $10 \mathrm{ppm}$, and the Nano-Se injection revealed intermediate FCR comparable to other groups.

It had been reported by Bartell and Batal (2007) and Salmanzadeh and Shahryar (2013b) that IO-GIn enhanced FCR and WG of broilers and Japanese quails due to the improvement of intestine. In this connection, Mehta et al (2016) indicated that chickens from IO-GIn showed a significantly greater BW and better WG of newly hatched chicks than those of the non-injected eggs. Whereas the IO-Nano-Se had no significant effect on broiler chicks performance (Abd-El-Fattah et al 2018).

The effect of 10 injection on carcass traits is shown in Table (2). It was observed that IO injection of Japanese quail eggs with Gln with either 20 or $10 \mathrm{ppm}$, just before incubation period had increased the percentages of eviscerated carcass significantly and breast muscles of chicks at 6 weeks of age when compared with the negative control group. The IO-Nano-Se (T3) realized nearly similar previous trend obtained with Gln, also it increased significantly small intestine percentage. Similarly, IO-Gln had led to increase the small intestine percentage, however, the absence of significance compared to the negative control. It is clear that liver percentages were slightly elevated with the injection of tested materials comparable to the non-injected group. 


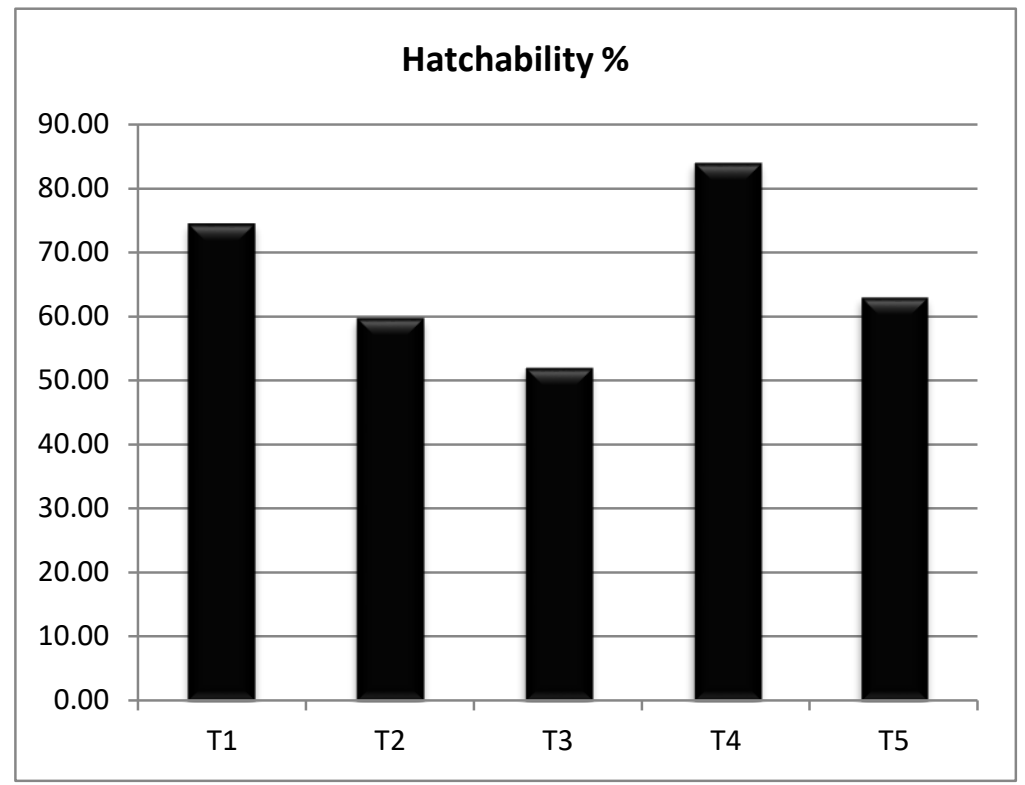

Fig. 1. Effect of In Ovo injection of Nano-Selenium and Glutamine on hatchability percentage

Table 1. Effect of In Ovo injection of Nano-Selenium and Glutamine on Performance of post-hatch chicks

\begin{tabular}{|c|c|c|c|c|c|c|}
\hline \multirow{2}{*}{ Trait } & \multicolumn{5}{|c|}{ Treatment } & \multirow{2}{*}{$\begin{array}{c}\text { P. } \\
\text { Value }\end{array}$} \\
\hline & T1 & T2 & T3 & T4 & T5 & \\
\hline \multicolumn{7}{|c|}{ Live Body Weight (gm) } \\
\hline $\begin{array}{c}\text { Initial Weight } \\
\text { (Day Old) }\end{array}$ & $8.73 \pm 0.12$ & $8.78 \pm 0.08$ & $8.81 \pm 0.18$ & $8.58 \pm 0.05$ & $8.80 \pm 0.08$ & 0.5827 \\
\hline $\begin{array}{c}\text { Final Weight } \\
\text { (6 Weeks) }\end{array}$ & $196.19^{b} \pm 1.95$ & $224.17^{\mathrm{a}} \pm 3.02$ & $201.71^{\mathrm{b}} \pm 2.89$ & $231.23^{\mathrm{a}} \pm 3.53$ & $233.13^{\mathrm{a}} \pm 4.12$ & $<.0001$ \\
\hline \multicolumn{7}{|c|}{ Weight Gain (gm) } \\
\hline $0-6$ Weeks & $187.46^{\mathrm{b}} \pm 1.92$ & $215.39^{\mathrm{a}} \pm 2.98$ & $192.90^{\mathrm{b}} \pm 2.93$ & $222.65^{\mathrm{a}} \pm 3.46$ & $224.33^{\mathrm{a}} \pm 4.08$ & $<.0001$ \\
\hline \multicolumn{7}{|c|}{ Feed Intake (gm) } \\
\hline 0-6 Weeks & $737.33^{b} \pm 4.33$ & $917.33^{\mathrm{a}} \pm 8.74$ & $721.33^{\mathrm{b}} \pm 10.41$ & $638.33^{c} \pm 10.14$ & $731.67^{b} \pm 1.76$ & $<.0001$ \\
\hline \multicolumn{7}{|c|}{ Feed Conversion } \\
\hline 0-6 Weeks & $3.94^{\mathrm{a}} \pm 0.06$ & $4.12^{\mathrm{a}} \pm 0.02$ & $3.75^{b} \pm 0.001$ & $2.85^{d} \pm 0.12$ & $3.31^{c} \pm 0.07$ & $<.0001$ \\
\hline
\end{tabular}

$a, b, c, \ldots .:$ In each row means having different letters are significantly different $(p<0.05)$.

(T1) Negative Control (no injection); (T2) Positive Control (solvent, BSA); (T3) Nano-Selenium (2.5 ppb/egg); (T4) Glutamine (20 ppm/egg); (T5) Glutamine (10 ppm/egg). 
Effect of in ovo nano-selenium and glutamine on hatchability, post-hatch performance and some blood biochemical indices in japanese quail

Table 2. Effect of In Ovo injection of Nano-Selenium and Glutamine on Carcass traits

\begin{tabular}{|c|c|c|c|c|c|c|}
\hline \multirow{2}{*}{ Trait } & \multicolumn{5}{|c|}{ Treatment } & \multirow{2}{*}{$\begin{array}{c}P . \\
\text { Value }\end{array}$} \\
\hline & $\mathrm{T} 1$ & $\mathrm{~T} 2$ & T3 & T4 & T5 & \\
\hline Carcass \% & $65.93^{b} \pm 0.96$ & $70.24^{a} \pm 1.56$ & $70.01^{a} \pm 0.58$ & $72.95^{\mathrm{a}} \pm 1.77$ & $73.74^{\mathrm{a}} \pm 1.12$ & 0.0020 \\
\hline Gizzard\% & $1.76^{b} \pm 0.08$ & $1.77^{b} \pm 0.09$ & $1.68^{b} \pm 0.03$ & $1.91^{b} \pm 0.06$ & $2.28^{a} \pm 0.16$ & 0.0105 \\
\hline Liver\% & $2.11^{c} \pm 0.12$ & $2.79^{a} \pm 0.13$ & $2.65^{\mathrm{ab}} \pm 0.36$ & $2.42^{b} \pm 0.12$ & $2.59^{a b} \pm 0.17$ & 0.0543 \\
\hline $\begin{array}{c}\text { Empty Small } \\
\text { Intestine\% }\end{array}$ & $4.16^{b} \pm 0.28$ & $6.03^{a} \pm 0.16$ & $5.65^{a} \pm 0.33$ & $4.61^{b} \pm 0.27$ & $4.71^{b} \pm 0.09$ & 0.0002 \\
\hline $\begin{array}{c}\text { Breast } \\
\text { Muscles\% }\end{array}$ & $18.76^{b} \pm 0.25$ & $19.72^{\mathrm{b}} \pm 1.14$ & $19.99^{b} \pm 0.62$ & $23.52^{\mathrm{a}} \pm 1.01$ & $23.36^{\mathrm{a}} \pm 1.5$ & 0.0080 \\
\hline
\end{tabular}

a,b,c....: In each row means having different letters are significantly different $(\mathrm{p}<0.05)$.

(T1) Negative Control (no injection); (T2) Positive Control (solvent, BSA); (T3) Nano-Selenium (2.5 ppb/egg); (T4) Glutamine (20 ppm/egg); (T5) Glutamine (10 ppm/egg).

Table 3. Effect of In Ovo injection of Nano-Selenium and Glutamine on Blood traits

\begin{tabular}{|c|c|c|c|c|c|c|}
\hline \multirow{2}{*}{ Trait } & \multicolumn{5}{|c|}{ Treatment } & \multirow{2}{*}{$\begin{array}{c}\text { P. } \\
\text { Value }\end{array}$} \\
\hline & T1 & T2 & T3 & T4 & T5 & \\
\hline $\begin{array}{l}\text { Total Proteins } \\
\qquad(\mathrm{g} / \mathrm{dl})\end{array}$ & $3.61 \pm 0.08$ & $3.84 \pm 0.18$ & $3.89 \pm 0.24$ & $3.44 \pm 0.17$ & $3.69 \pm 0.12$ & 0.3606 \\
\hline Albumin $(\mathrm{g} / \mathrm{dl})$ & $1.36^{\mathrm{bc}} \pm 0.04$ & $1.54^{\mathrm{ab}} \pm 0.06$ & $1.64^{a} \pm 0.10$ & $1.27^{\mathrm{c}} \pm 0.07$ & $1.43^{\mathrm{bc}} \pm 0.04$ & 0.0039 \\
\hline Globulin (g/dl) & $2.26 \pm 0.08$ & $2.29 \pm 0.14$ & $2.23 \pm 0.13$ & $2.17 \pm 0.11$ & $2.26 \pm 0.08$ & 0.9583 \\
\hline $\mathrm{A} / \mathrm{G}$ ratio & $0.602^{c} \pm 0.032$ & $0.672^{\mathrm{ab}} \pm 0.022$ & $0.735^{\mathrm{a}} \pm 0.019$ & $0.585^{c} \pm 0.013$ & $0.633^{\mathrm{bc}} \pm 0.010$ & $<.0001$ \\
\hline $\begin{array}{l}\text { Cholesterol } \\
(\mathrm{mg} / \mathrm{dl})\end{array}$ & $133.39^{\mathrm{ab}} \pm 6.08$ & $142.21^{a} \pm 4.37$ & $125.13^{b} \pm 4.23$ & $135.04^{\mathrm{ab}} \pm 2.38$ & $127.80^{\mathrm{ab}} \pm 5.59$ & 0.03516 \\
\hline $\begin{array}{l}\text { Triglycerides } \\
(\mathrm{mg} / \mathrm{dl})\end{array}$ & $64.83^{\mathrm{bc}} \pm 3.61$ & $86.91^{\mathrm{a}} \pm 1.39$ & $60.75^{c} \pm 3.86$ & $74.81^{\mathrm{ab}} \pm 5.06$ & $81.37^{\mathrm{a}} \pm 5.01$ & 0.0021 \\
\hline $\mathrm{HDL}(\mathrm{mg} / \mathrm{dl})$ & $75.64^{b} \pm 5.14$ & $72.56^{\mathrm{b}} \pm 4.44$ & $64.53^{\mathrm{b}} \pm 3.20$ & $114.12^{\mathrm{a}} \pm 1.22$ & $103.61^{\mathrm{a}} \pm 4.5$ & $<.0001$ \\
\hline LDL (mg/dl) & $59.71^{\mathrm{a}} \pm 3.48$ & $47.63^{b} \pm 3.96$ & $43.04^{b c} \pm 3.29$ & $35.36^{\mathrm{cd}} \pm 3.68$ & $29.5^{\mathrm{d}} \pm 1.85$ & 0.0004 \\
\hline
\end{tabular}

$a, b, c, \ldots .$. In each row means having different letters are significantly different $(p<0.05)$.

(T1) Negative Control (no injection); (T2) Positive Control (solvent, BSA); (T3) Nano-Selenium (2.5 ppb/egg); (T4) Glutamine (20 ppm/egg); (T5) Glutamine (10 ppm/egg).

Our results on breast muscle are similar to those findings of Chen et al (2013) who found that IO-GIn resulted in a significant increase in the breast muscles size during the incubation period compared to the control. Also, Yi et al (2005) and Fischer da Silva et al (2007) found that Gln can stimulate the small intestine development in poults. In this respect, Le-Bacquer et al (2003) reported that the Gln supplement is very important to pro- tein structure of mucus and the formation of small intestine barrier.

On the other hand, the significant increased in carcass \% as a result of IO-nano-Se (2.5 ppb / egg) was similar to those of Patric et al (2016) who showed that the IO-Nano-Se of broiler eggs cleared significantly highest carcass $\%$ and had no significant effect on breast muscle \% as compared to control. 
Results in Table (3) showed insignificant differences among all experimental groups concerning plasma total protein and globulin. While, albumin concentration was elevated $(p \leq 0.004)$ in quail chicks whose eggs were 10 injected with Nano-Se at $2.5 \mathrm{ppb}$ / egg, when compared with chicks of all remaining treatment groups. Similar trend was obtained for $A / G$ ratio data. These results may be due to increasing the BWG by increasing the IOGIn (T4 and T5).

Similar reports were observed by El-Said (2015) who found no significant effect of globulin with group of Nano-Se $20 \mathrm{ppb}$ and Selim et al (2015) who showed that no significant difference at 0.15 and $0.30 \mathrm{ppm}$ in diet or drinking water on plasma total protein and globulin. Whereas, supplementing Nano-Se increased plasma concentration of total protein, albumin and significant difference in globulin (Abd El-Fatah et al 2018). On the other hand, Kanagaraju and Rathnapraba (2017) reported similar results that IO-GIn had no significant differences in plasma total protein, albumin and globulin compared with sham control but had significant differences in the same parameters compared with control group.

Results of plasma lipid profiles showed that, chicks derived from eggs that were injected with Nano-Se recorded insignificantly lesser plasma concentration of cholesterol, triglycerides and HDL compared to chicks of non-injected group. But when compared with Gln chicks group, Nano-Se chicks had significantly lower triglycerides and HDL. Injection of Japanese quail breeder eggs at a period of pre-incubation resulted in significant elevation in the plasma concentration of HDL in the blood of produced chicks at 6 week of age comparable to the chicks produced from non-injected eggs. Significant higher concentration of LDL were obtained for negative and positive groups than the groups of Nano-Se and Gln.

This result is in agreement with that reported by Abd El-Fatah et al (2018) and Saleh (2014) who cleared that using Nano-Se had no significant differences on plasma cholesterol and triglycerides levels. However, these results disagree with that reported by El-Said (2015) who found a significant increase in HDL when used Nano-Se at $40 \mathrm{ppb}$, but no effect was obtained with group received Nano-Se at $20 \mathrm{ppb}$.

\section{CONCLUSION}

In conclusion, it could be concluded that using in ovo administration of GIn and Nano-Se concentration for Japanese quail breeder eggs, had no negative effect on hatchability and could improve post-hatched performance carcass traits, particularly using Gln at a dosage of 20 ppm / egg.

\section{REFERENCES}

Abd El-Fatah M.M., El-Wardany I., Abdallah E.A. and Marwa Sh. Abdo 2018. Influence of in ovo injection of selenium nanoparticles and selenomethionine on growth performance and physiological parameters of broiler chicks. Arab Univ. J. Agric. Sci., Ain Shams Univ., Cairo, Special Issue, 26(2A), 1097-1107.

Bartell S.M. and Batal A.B. 2007. The effect of supplemental glutamine on growth performance, development of the gastrointestinal tract, and humoral immune response of broilers. Poult. Sci., 86, 1940-1947.

Bertolo R.F. and Burrin D.G. 2008. Comparative aspects of tissue glutamine and proline metabolism. J. Nutr., 38, 2032S-2039S.

Calder P.C. and Yaqoob P. 1999. Glutamine and the immune system. Amino Acids, 17, 227241.

Duncan D.B. 1955. Multiple ranges and multiple Ftest. Biometrics, 11, 1-42.

Eman A. El-Said 2015. Influence of in-ovo injection (feed-ing) with Nano particles Selenium (SeNPs) on growth performance, carcass yield and immune status of broiler chickens. Ph.D. Thesis. Fac. Agric., Damietta Univ., Egypt, pp. 48-102.

Fischer Da Silva A.V., Maiorka A., Borges S.A., Santin E., Boleli I.C. and Macari M. 2007. Surface area of the tip of the enterocytes in small intestine mucosa of broilers submitted to early feed restriction and supplemented with glutamine. Int. J. of Poultry Sci., 1, 31-35.

Foye O.T., Uni Z. and Ferket P.R. 2006a. Effect of in ovo feeding egg white protein, betahydroxy-beta-methylbutyrate, and carbohydrates on glycogen status and neonatal growth of turkeys. Poult. Sci., 85(7), 1185-1192.

Foye O.T., Uni Z., McMurtry J.P. and Ferket R.P., 2006b. The effects of amniotic nutrients administration, in ovo feeding of arginine and/or $\beta$-hydroxy $\beta$-methylbutyrate (HMB) on insulinlike growth factors, energy metabolism and growth in turkey poults. Int. J. Poult. Sci. 5, 309-317.

Friedewald W.T., Levy R.I. and Fredrickson D.S. 1972. Estimation of the Concentration of LowDensity Lipoprotein Cholesterol in Plasma, without Use of the Preparative Ultracentrifuge. Clinical Chemistry, 18, 499-502.

Kanagaraju P. and Rathnapraba S. 2017. Effect of In-Ovo Supplementation of Vital Nutrients on the Production Performance and Gut Histomorphology of Commercial Broiler Chicken. Int. J. of Livestock Research, 7(12), 199-205. 

performance and some blood biochemical indices in japanese quail

Le Bacquer O., Laboisse C. and Dominique D. 2003. Glutamine preserve protein synthesis and paracellular permeability in Caco-2 cells submitted to "luminal fasting". American J. of Physiology. Gastrointestinal and Liver Physiology, 285, 128-136.

Lopes-Virella M.F., Stone P., Ellis S. and Colwell J.A. 1977. Cholesterol determination in high-density lipoproteins separated by three different methods. Clin. Chem., 23(5), 882-884.

National Research Council, 1994. Nutrient Requirements Council National Academic of Sci. Washington, DC.USA.

NCEP, 1988. Report of the National Cholesterol Education Program Expert Panel on Detection, Evaluation, and Treatment of High Blood Cholesterol in Adults. Arch. Intern. Med., 148, 3669.

Patric Joshua P., Valli C. and Balakrishnan V. 2016. Effect of in ovo supplementation of Nano forms of zinc, copper, and selenium on posthatch performance of broiler chicken. Veterinary World, 9, 11.

Pedroso A.A., Chaves L.S., Lopes K.L.D.M., Leandro N.S.M., Café M.B. and Stringhini J.H. 2006b. Nutrient inoculation in eggs from heavy breeders. Rev. Bras. Zootecn., 35, 2018-2026.

Saleh A.A. 2014. Effect of dietary mixture of Aspergillus probiotic and selenium nanoparticles on growth, nutrient digestibilities, selected blood parameters and muscle fatty acid profile in broiler chickens. Animal Sci. Papers and Reports 32(1), 65-79.

Salmanzadeh M. 2011. The effects of in ovo injection of glucose on hatchability, hatching weight and subsequent performance of newly hatched chicks. Braz. J. Poult. Sci., 14, 137-140.

Salmanzadeh M., Ebrahimnezhad Y., Shahryar H.A. and Beheshti R. 2012. The effects of in ovo injection of glucose and magnesium in broiler breeder eggs on hatching traits, performance, carcass characteristics and blood parameters of broiler chickens. Arch. Geflügelk., 76, 277-284.

Salmanzadeh M. and Shahryar H.A. 2013. Effects of dietary glutamine addition on growth performance, carcass characteristics and development of the gastrointestinal tract in Japanese quails. Revue. Méd. Vét., 164, 471-475.

SAS, 2002. SAS/STAT®User's Guide: Statistics Ver. $9.1 .3,5^{\text {th }}$ ed. SAS Institute Inc. Cary, NC., USA.

Sawosz F., Pineda L., Hotowy A., Hyttel P., Sawosz E., Szmidt M., Niemiec T. and Chwalibog A. 2012. Nano-nutrition of chicken embryos. Effect of silver nanoparticles and glutamine on molecular responses and morphology of pectoral muscle. Balt. J. Comp. Clin. Syst. Bio., 2, 29-45.

Selim N.A., Radwan N.L., Youssef S.F., Salah Eldin T.A. and Abo Elwata S. 2015. Effect of inclusion inorganic, organic or nano selenium forms in broiler diets on: 2-Physiological, immunological and toxicity statuses of broiler chicks. Int. J. of Poultry Sci., 14(3), 144-155.

Shafey T.M., Al-Batshan H.A., Al-Owaimer A.N. and Al-Samawei K.A. 2010. Effects of in ovo administration of L-carnitine on hatchability performance, glycogen status and insulin-like growth factor-1 of broiler chickens. Br. Poult. Sci. 51, 122-131.

Smirnov A., Tako E., Ferket P.R. and Uni Z. 2006. Mucin gene expression and mucin content in the chicken intestinal goblet cells are affected by in ovo feeding of carbohydrates. J. Poult. Sci., 85, 669-673.

Sunny N.E., Adamany J. and Bequette B.J. 2007. Gluconeogenesis and carbon utilization in embryos from small and large chicken eggs. FASEB J., 21, 543-545.

Tako E., Ferket P.R. and Uni Z. 2004a. Effects of in ovo feeding of carbohydrates and betahydroxy-beta-methyl butyrate on the development of chicken intestine. Poult. Sci. 83, 20232028.

Tako E., Ferket P.R. and Uni Z. 2004b. Changes in chicken intestinal zinc exporter mRNA expression and small intestinal functionality following intra-amniotic zinc-methionine administration. J. Nutr. Biochem., 16, 339-346.

Tietz N.W. 1990. Clinical Guide to laboratory tests. $2^{\text {nd }}$ ed. Philadelphia, W.B. Saunders, pp. 2629.

Tietz N.W. 1994. Fundamentals of Clinical Chemistry. $2^{\text {nd }}$ ed. NW Tietz.

Tong B.C. and Barbul A. 2004. Cellular and physiological effects of arginine. Mini Rev. Med. Chem. 4, 823-832.

Uni Z. and Ferket P.R. 2004. Methods for early feeding and their potential. World Poult. Sci. J., 60, 101-111.

Uni Z., Ferket P., Tako E. and Kedar O. 2005. In ovo feeding improves energy status of late term chicken embryos. Poult. Sci., 84, 764-770.

Yi G.F., Allee G.L., Knight C.D. and Dibnert J.J. 2005. Impact of glutamine oasis hatchling supplement on growth performance, small intestinal morphology, and immune response of broiler vaccinated and challenged with eimeria maxima. Poultry Sci., 84, 283-293.

Young D.S., Pestaner L.C. and Gibberman V. 1975. Effects of drugs on clinical laboratory tests. Clin. Chem., 1D-432D. 


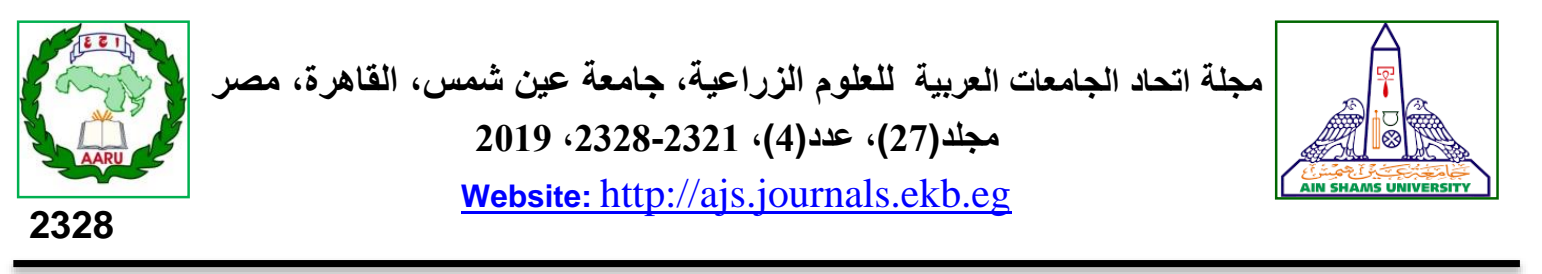

تأثير الحقن بالنانو سيلينيوم والجلوتامين على الفقس، الأداء الأنتاجي بعد الفقس وبعض فئل مؤشرات الام البيوكيميائية في السمان الياباني

[185]

$$
\begin{aligned}
& \text { محمد جمال سلام1" - إبراهيم الورداني2 - سيد أحمد عبد الفتاح2 - }
\end{aligned}
$$

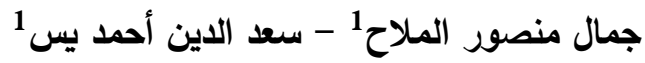

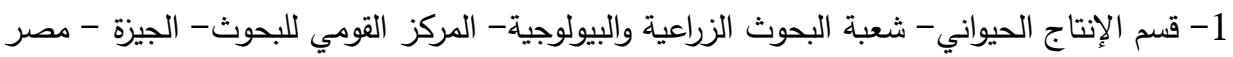

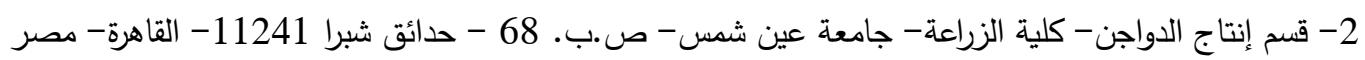

*Corresponding author: mohamed sallam@agr.asu.edu.eg

Received 12 September, 2019

Accepted 24 September, 2019

وجد أن حقن البيض بالجلوتامين بنسبة 20 جزء في المليون لكل بيضة قام بتحسين نسبة الفقس، وزئ وزيادة

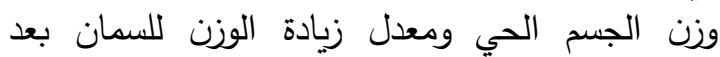

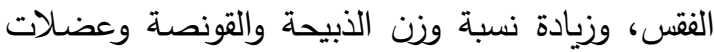

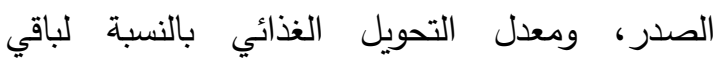
المجموعات. وعلاوة علي ذلك، الحقن بالنانوسيلينيوم لإيلية

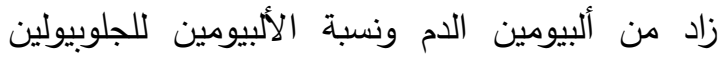

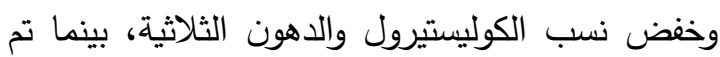

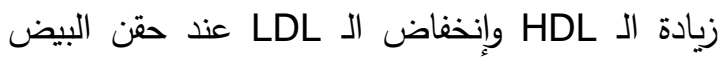

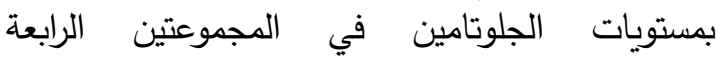
والخامسة. ونستنتج من ذلك أن الحقن بالنانو سيلينوم

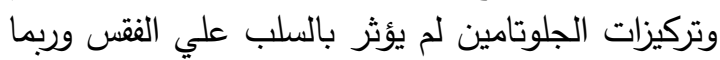

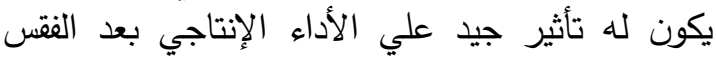

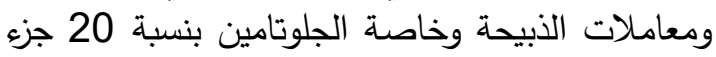

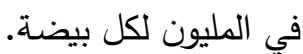

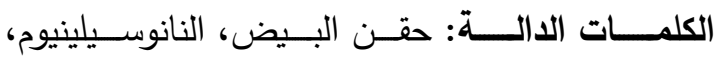
الجلوتامين، نسبة الفقس، الأداء الإنتاجي، السمان الني النان

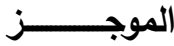

الهدف الرئيسي من هذه الدراسة هو قياس نسبة الفقس والأداء بعد الفقس مثل وزن الجنس الجسم ومعدل التحويل الغذائي ومواصفات الذبيحة وبعض الأبل القياست

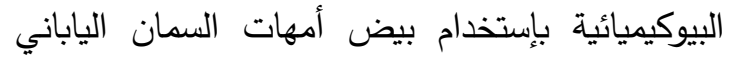
المخصب وحقنه بالنانوسيلينيوم والجلوتامين.

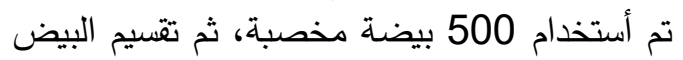
إلى خمس مجموعات وحقنه قبل التحضين مباشرة

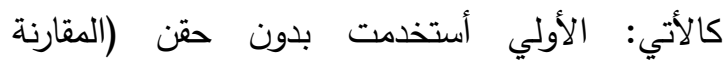

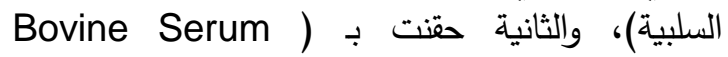
(المقارنة الأيجابية)، تم حقن المجموعة (Albumin الثالثة بالنانوسيلنيوم بتركيز 2.5 جزء في المليار لكلة فئل بيضة، بينما تم حقن المجموعتين الربعة والخامسة بالجلوتامين بتركيز 20 و 10 جزء في المليون لكل التل بيضة على التوالي. وتم توزيع الكتاكيت بعد الفتس وفت وفقا

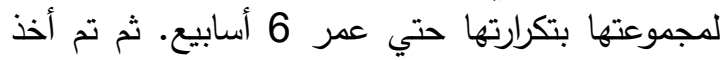
بعض القياسات مثل نسبة الفقس، وزن الكتاكيت

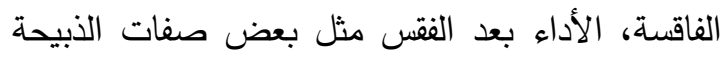

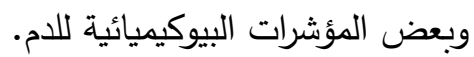


